\title{
Investigation of biological activities of the flowers of Lagerstroemia speciosa, the Jarul flower of Bangladesh
}

\author{
Tasnuva Sharmin ${ }^{1 *}$, Md. Shahidur Rahman ${ }^{2}$ and Habiba Mohammadi ${ }^{3}$
}

\begin{abstract}
Background: Lagerstroemia speciosa (L.) Pers. (Family: Lythraceae) is used in traditional medicine in the treatment of diarrhea, diabetes and other diseases. The study was performed to conduct antioxidant, cytotoxic, thrombolytic, membrane stabilizing, antimicrobial, peripheral and central analgesic and hypoglycemic activity assays and phenobarbitone sodium-induced sleeping time test using crude methanol extract of flowers of $L$. speciosa and its different partitionates.
\end{abstract}

Method: The antioxidant potential was evaluated by determining the ability of the samples to scavenge 1, 1-diphenyl2-picrylhydrazyl (DPPH) free radical. The cytotoxic potential was examined following the procedures of brine shrimp lethality bioassay. Thrombolytic potential was assayed using streptokinase as standard. The samples were subjected to membrane stabilizing activity assay under heat induced condition. Antimicrobial potential was observed by disc diffusion method. The ability of the extract to inhibit writhing induced by acetic acid was determined in peripheral analgesic activity assay. The extract was also tested for central analgesic and hypoglycemic activities by tail flicking and tail tipping methods in Swiss albino mice model, respectively. CNS depressant activity was evaluated by an assay in which sleep was induced in mice using phenobarbitone sodium.

Results: The chloroform soluble fraction of $L$. speciosa extract demonstrated the highest antioxidant activity $\left(I C_{50}=\right.$ $4.20 \pm 0.41 \mathrm{\mu g} / \mathrm{ml})$ while the most prominent cytotoxic potency was showed by hexane soluble fraction $\left(\mathrm{LC}_{50}=2.00 \pm\right.$ $0.31 \mu \mathrm{g} / \mathrm{ml})$. Among the test samples, the carbon tetrachloride soluble fraction induced clot lysis $(64.80 \pm 0.27 \%)$ and prevented heat induced haemolysis $(41.90 \pm 0.10 \%)$ to the maximum extent. The largest zone of inhibition (19.0 mm) against Staphylococcus aureus, was also observed for the same fraction. In peripheral analgesic activity assay, 16.68\% inhibition of writhing was documented for the L. speciosa extract ( $400 \mathrm{mg} / \mathrm{kg}$ body weight dose). The extract (400 mg/kg dose) also reduced blood sugar level by $56.12 \%$ after three hours of administration of glucose solution. In CNS depressant activity assay, mice of the sample group slept for shorter period of time compared to control group.

Conclusions: From our investigation, it can be suggested that, the extract should be further studied for possible phytochemicals responsible for the observed biological activities.

Keywords: Lagerstroemia speciosa, Free radical scavenging activity, Brine shrimp lethality, Thrombolysis, Disc diffusion assay, Zone of inhibition, Writhing, Anti-nociception, Tail tipping method

\footnotetext{
*Correspondence: tasnuva.phr.du@gmail.com

'Department of Pharmaceutical Chemistry, Faculty of Pharmacy, University of

Dhaka, Dhaka, Bangladesh

Full list of author information is available at the end of the article
}

(c) The Author(s). 2018 Open Access This article is distributed under the terms of the Creative Commons Attribution 4.0 International License (http://creativecommons.org/licenses/by/4.0/), which permits unrestricted use, distribution, and reproduction in any medium, provided you give appropriate credit to the original author(s) and the source, provide a link to the Creative Commons license, and indicate if changes were made. The Creative Commons Public Domain Dedication waiver (http://creativecommons.org/publicdomain/zero/1.0/) applies to the data made available in this article, unless otherwise stated. 


\section{Background}

Lagerstroemia speciosa (L.) Pers. (Synonyms: Adambea glabra Lam., Lagerstroemia major Retz., Munchausia speciosa) is locally known as Jarul or Banaba (Family: Lythraceae). It is a small to medium sized or rarely large deciduous or semi-deciduous tree that grows abundantly in tropical and subtropical regions [1, 2]. Almost every plant part of $L$. speciosa is found to have several important biological properties. Leaves, roots and bark have several traditional uses [3, 4]. Leaf is used in hypercholesterolemia, hypertension, diabetes, different renal dysfunctions and to prepare slimming tea. Bark of the plant is locally used to treat diarrhea $[4,5]$. The leaf extract of L. speciosa is reported as nephroprotective [6], hepatoprotective [7] and to have diuretic activity [8]. Leaf extract has been reported to have antioxidant activity while bark extract has been found to show cytotoxicity against Artemia salina [9-12]. Because of its anti-diabetic effects with no evident side effect, its use is considered the most efficacious and practical approach for 'ethno-pharmacologically' managing diabetes [13]. Herbal products such as Banabamin and Glucosol TM have been recently marketed from this 'natural plant insulin' [14, 15]. Its hypoglycemic effect has been evaluated in rabbit [16], mouse [17], alloxan-induced diabetic mice, streptozotocin-induced diabetic rats and type 2 diabetic rats [9, 18-23]. Phase II and III clinical trials with $L$. speciosa leaf decoctions showed promising results in the management of diabetes mellitus $[24,25]$. Although it was thought that an insulin-like peptide hormone contributes to the hypoglycemic activity, it has been recently revealed that corosolic acid, a phytocomponent from $L$. speciosa, possesses free radical scavenging and hypoglycemic properties in animal model [24-27]. In addition the analgesic effect of root and fruit extracts (200 and $500 \mathrm{mg} / \mathrm{kg}$ body weight doses, respectively) was observed in animal model and the outcomes justify its traditional use [1, 28, 29]. The leaf extract also exhibited analgesic and anti-inflammatory activities against different chemical and thermal stimuli [30]. All these assays were found to be quite promising upon assays on animal model. Research should be conducted with flower extract of L. speciosa on animal model for the evaluation of different bioactivities since very limited number of studies have been conducted using the flowers of the plants.

To date, more than 40 compounds including triterpenes, tannins, ellagic acids, glycosides and flavones have been identified from the leaves of $L$. speciosa. Of the 14 compounds identified, four were new to the genus and family, and one was new to the species [31]. A series of ellagitannins and pentacyclic triterpenes, ellagic acid and its derivatives, a new tritrpenoid, corosolic acid, valoneic acid dilactone, quercetin, isoquercitin, virgatic acid, ursolic acid, $\beta$-sitosterol glucoside and some other phytocomponents were isolated and identified from $L$. speciosa extract [32-38].

We have been trying to investigate a few medicinal plants of Bangladesh for prominent biological activities [39-41]. The plants with promising history of traditional use are mainly chosen for research. The isolated phytoconstituents, traditional uses and the reported biological properties, have made $L$. speciosa a highly promising subject for further studies. The flowers of $L$. speciosa are very abundant in Bangladesh during the summer season and very limited number of research was carried out using the flowers of the plant. Therefore, we have conducted antioxidant, cytotoxic, thrombolytic, membrane stabilizing, antimicrobial, peripheral and central analgesic and hypoglycmic activity assays and phenobarbitone sodium-induced sleeping time test using $L$. speciosa flower extract.

\section{Methods \\ Plant materials}

In May 2015, L. speciosa flowers were procured from the premises of University of Dhaka, Bangladesh. This collection was identified by Mrs. Monira Begum. She is a botanist and $\mathrm{PhD}$ student of University of Dhaka. For this procurement, she provided a voucher specimen (DUSH - 5945) which was then preserved in Dhaka University Salar Khan Herbarium.

The plant materials were cleaned thoroughly and cut into small pieces. They were dried under sun and finally powdered when they were dry enough for proper grinding. Using $1.5 \mathrm{~L}$ Methanol, the powder (300 g) was kept macerated for a week under room temperature. Then the plant material was filtered and the corresponding filtrate was evaporated to dryness using a rotary evaporator at $40{ }^{\circ} \mathrm{C}$ and 50 r.p.m. to give the crude methanol extract. Following the modified Kupchan [42] partition protocol, the extract $(5 \mathrm{~g})$ was dissolved in $10 \%(\mathrm{v} / \mathrm{v})$ aqueous methanol and transferred to a separating funnel. After pouring $100 \mathrm{ml}$ hexane, the funnel was shaken and kept undisturbed so that the aqueous and organic layers could separate. The organic layer was collected. The process was repeated three times. $12.5 \mathrm{ml}$ distilled water was added to the solution left after partitioning with hexane and then the mixture was extracted with $100 \mathrm{ml}$ carbon tetrachloride. The organic layer was collected and the process was repeated three times. After that $16 \mathrm{ml}$ distilled water was added to the funnel and the aqueous fraction was then extracted with $100 \mathrm{ml}$ chloroform. The aqueous layer was partitioned with chloroform three times and the organic layer was collected. The aqueous methanolic fraction was further used as aqueous soluble fraction. All the partitionates were concentrated using rotary evaporator to yield hexane (HXSF, $1.0 \mathrm{~g}$ ), carbon tetrachloride (CTCSF, $1.1 \mathrm{~g}$ ), chloroform (CSF, $1.0 \mathrm{~g}$ ) 
and aqueous (AQSF, $1.0 \mathrm{~g}$ ) soluble fractions. They were then preserved in the refrigerator.

\section{Animal}

For the assays on animal model, Swiss-albino mice were used. The mice were of either sex aging 5-6 weeks with an average weight of $25 \mathrm{~g}$. The mice were provided by the International Centre for Diarrheal Diseases and Research, Bangladesh (ICDDR, B). The mice were healthy and free from any known infection. Before initiating the experiments, the animals were held and observed for 15 days so that they could adapt to laboratory circumstance. $120 \times 30 \times 30 \mathrm{~cm}$ cages were used and standard laboratory environment (room temperature $25 \pm 2{ }^{\circ} \mathrm{C}$; relative humidity $55-60 \%$; 12 h light-dark cycle) was maintained. None was allowed inside the animal room during the dark phase. Experiments were conducted in the light cycle. The animals were fed with ICDDR, B formulated rodent food and tap water ad libitum. These were freely accessible to them. For the experiments the animals were picked randomly and were kept fasting overnight before experiments [43]. During experiment, any actual or considerable suffering or distress were monitored and lessened. For each test, the experimental unit was individual animal. After each experiment, carbon dioxide gas and cervical dislocation or decapitation method was used for anesthesia and euthanasia in order to minimize physical and mental sufferings of the animals. They were placed inside a transparent glass chamber so that they could be observed during exposure to carbon dioxide. Carbon dioxide gas cylinder, equipped with pressure regulator and flowmeter, was previously collected from local source. The gas was supplied in such a rate so that it could displace $10-30 \%$ of the chamber volume per minute. The gas concentration was slowly increased so that the animals lose consciousness because of loss of cerebral activity than suffocate to death due to exposure to $100 \%$ carbon dioxide. When all the animals became unconscious, the rate of gas flow was increased slowly to fill the chamber and decrease the time to death. After that, a secondary physical method (either decapitation or cervical dislocation) was utilized prior to disposal of the carcass. In decapitation, the animals were placed in the guillotine and their heads were chopped off. Since this process was untidy and uncomfortable for the operator, cervical dislocation method was used for euthanasia. In this method, a metal rod was placed quickly across the neck and pressed down hard while the body was jerked backwards by pulling on the tail. As a result, the neck became dislocated. The body was then examined for respiratory arrest and absence of heart beat before final disposal. Tests were conducted in accordance with The Swiss Academy of Medical Sciences and the Swiss Academy of Sciences formulated
Ethical Principles and Guidelines for Scientific Experiments on Animals (1995) and performed under the approval of Ethics Committee of State University of Bangladesh through the submission of a research protocol (FHU/SUB/23/2014) before the study.

\section{Drugs and chemicals}

Streptokinase and morphine were supplied by Beacon Pharmaceutical Ltd. and Gonoshastho Pharmaceuticals Ltd. Dhaka, Bangladesh, respectively. Diclofenac sodium $\mathrm{BP}$ and phenobarbitone sodium were obtained from Incepta Pharmaceuticals Ltd., Dhaka, Bangladesh. The rest of the drugs, reagents and solvents were obtained from Sigma-Aldrich, Munich, Germany.

\section{Total phenolic content}

Total phenolic content of the extract and the aqueous and organic soluble fractions was determined using Folin-Ciocalteau reagent [44]. At first, the reagent was diluted 10 times. $2.5 \mathrm{ml}$ of the diluted reagent and $2.0 \mathrm{ml}$ of sodium carbonate $(7.5 \%, w / v)$ were added to the samples $(2 \mathrm{mg} /$ $\mathrm{ml}$ water). The sample was incubated for $15 \mathrm{~min}$ at $45^{\circ} \mathrm{C}$ before taking the absorbance at $765 \mathrm{~nm}$.

\section{DPPH free radical scavenging activity assay}

In this assay, the ability of the test samples to scavenge DPPH free radical was assessed using BHT and ascorbic acid as standards [45]. Calculated amount of different samples were measured and dissolved in methanol to get a concentration of $1000 \mu \mathrm{g} / \mathrm{ml}$. Serial dilution of this solution gave different concentrations ranging from 500 to $0.977 \mu \mathrm{g} / \mathrm{ml}$ which were then mixed with $3.0 \mathrm{ml}$ $\mathrm{DPPH}$ solution $(20 \mu \mathrm{g} / \mathrm{ml})$ in methanol. All the test tubes were then kept in dark for $30 \mathrm{~min}$ at room temperature before taking absorbance at $517 \mathrm{~nm}$. The $\mathrm{IC}_{50}$ values (concentration of the extract providing $50 \%$ inhibition of oxidation) were calculated by plotting concentration of the samples versus percentage inhibition of free radical.

\section{Brine shrimp lethality bioassay}

In this method, Artemia salina leach (brine shrimp egg) was hatched in simulated sea water to give brine shrimp nauplii [46]. Dimethylsulfoxide (DMSO) was used for sample preparation and serial dilution was done to give different concentrations $(400 \mu \mathrm{g} / \mathrm{ml}$ to $0.781 \mu \mathrm{g} / \mathrm{ml})$. $5 \mathrm{ml}$ simulated sea water was taken in pre-marked vials into which ten brine shrimp nauplii and test samples were transferred. The vials were then set aside for $24 \mathrm{~h}$. After that, the vials were inspected using a magnifying glass and the number of survivors was counted. $\mathrm{LC}_{50}$ (median lethal concentration) values were calculated by plotting the logarithm of sample concentration against percentage mortality of the shrimp nauplii. The assay 
results were then compared with that of vincristine sulphate, which was used as positive control.

\section{Thrombolytic activity assay}

Following the method developed by Prasad et al. (2006) [47], the thrombolytic action of the plant extract and the aqueous and organic soluble fractions was determined. Streptokinase was used as positive control in this assay. Pre-weighed sterile micro-centrifuge tubes were taken. $5 \mathrm{ml}$ venous blood was distributed in them. All the tubes were then incubated at $37{ }^{\circ} \mathrm{C}$ for $45 \mathrm{~min}$. Serum was removed carefully after clot formation and the clot weight was determined. $100 \mu \mathrm{l}$ aqueous solution of different samples $(10 \mathrm{mg} / \mathrm{ml}$ water), $100 \mu \mathrm{l}$ of streptokinase (positive control) and $100 \mu \mathrm{l}$ of distilled water (negative control) were added separately to tubes containing pre-weighed clot. After incubation at $37{ }^{\circ} \mathrm{C}$ for $90 \mathrm{~min}$, the released fluid was removed with care. Tubes were again weighed. The differences in weights were used to determine percentage of clot lysis according to the following equation:

Percent of clot lysis $=$ (weight of released clot/clot weight $)$ $\times 100 \%$

\section{Membrane stabilizing activity}

The ability of the test samples to inhibit heat induced haemolysis of human erythrocytes was assessed following the method of Omale et al. (2008) [48]. Samples $(1 \mathrm{mg} / \mathrm{ml} \mathrm{methanol})$ were distributed between two duplicate sets of centrifuge tubes. $4.5 \mathrm{ml}$ isotonic buffer was added to each of them to make the volume $5 \mathrm{ml}$. Another tube containing the isotonic buffer alone was used as negative control. $30 \mu$ erythrocyte suspension was added to each tube and mixed gently by inversion. One set of the tubes was taken in water bath of $54{ }^{\circ} \mathrm{C}$ temperature and incubated for $20 \mathrm{~min}$. The other set was placed in an ice bath of $0^{\circ}-5{ }^{\circ} \mathrm{C}$ temperature. After centrifugation ( $3 \mathrm{~min}$ at
$1300 \mathrm{~g}$ ), the absorbance of the supernatant was determined at $540 \mathrm{~nm}$ using the isotonic buffer as blank. Percentage inhibition or acceleration of haemolysis was calculated using the following equation:

$$
\begin{aligned}
& \text { Percent inhibition of haemolysis } \\
& \quad=100 \times\left[1-\left(\mathrm{OD}_{2}-\mathrm{OD}_{1} / \mathrm{OD}_{3}-\mathrm{OD}_{1}\right)\right] \%
\end{aligned}
$$

where, $\mathrm{OD}_{1}=$ optical density of unheated test sample, $\mathrm{OD}_{2}=$ optical density of heated test sample and $\mathrm{OD}_{3}=$ optical density of heated control sample.

\section{Antimicrobial screening}

The extract and its different fractions were evaluated by disc diffusion method [49] to determine their antimicrobial potencies. The samples were taken at a dose of $400 \mu \mathrm{g} / \mathrm{disc}$. In this investigation, ciprofloxacin and fluconazole $(30 \mu \mathrm{g} /$ disc) discs were used as antibacterial and antifungal references respectively. At first, the bacterial and fungal strains were transferred to previously sterilized and melted nutrient agar media. Then the preparations were poured onto sterilized petri dishes and allowed to solidify under laminar air flow hood. Then the petri dishes were kept in refrigerator until further use. Each test sample was dissolved in an appropriate solvent (chloroform or methanol) in such a way that $400 \mu \mathrm{g}$ sample could be transferred to each disc. The discs were then dried with care under laminar air flow and placed on previously sterilized petri dishes with the help of semiautomatic pipette. Standard discs were placed as well. All the petri dishes were placed inside refrigerator at $4{ }^{\circ} \mathrm{C}$ for $24 \mathrm{~h}$ and then inside an incubator at $37{ }^{\circ} \mathrm{C}$ for $24 \mathrm{~h}$. After incubation, zone of inhibition was measured. The Institute of Nutrition and Food Science (INFS) of University of Dhaka supplied the pure microbial cultures.

\section{Peripheral analgesic activity}

In peripheral analgesic activity assay, acetic acid was injected intraperitonially to induce abdominal pain

Table 1 Antioxidant and cytotoxic activities of L. speciosa flower extract and soluble fractions

\begin{tabular}{llll}
\hline Samples/Standards & $\begin{array}{l}\text { Total phenolic content } \\
(\mathrm{mg} \text { of GAE/g of dried extract) }\end{array}$ & $\begin{array}{l}\text { Free radical scavenging } \\
\text { activity } I C_{50}(\mu \mathrm{g} / \mathrm{ml})\end{array}$ & $\begin{array}{l}\text { Brine shrimp lethality } \\
\text { bioassay } L C_{50}(\mu \mathrm{g} / \mathrm{ml})\end{array}$ \\
\hline ME & $17.71 \pm 0.32$ & $4.50 \pm 0.11$ & $25.70 \pm 0.19$ \\
HXSF & $11.15 \pm 0.56$ & $32.11 \pm 0.58$ & $2.00 \pm 0.31$ \\
CTCSF & $9.94 \pm 0.13$ & $5.15 \pm 0.21$ & $15.06 \pm 0.43$ \\
CSF & $1.42 \pm 0.44$ & $4.20 \pm 0.41$ & $18.37 \pm 0.32$ \\
AQSF & $19.34 \pm 0.49$ & $10.92 \pm 0.33$ & $84.02 \pm 0.13$ \\
Vincristine sulfate & - & - & $0.45 \pm 0.04$ \\
BHT & - & $27.50 \pm 0.54$ & - \\
Ascorbic acid & - & $5.80 \pm 0.21$ & -
\end{tabular}

$\mathrm{ME}=$ Methanolic crude extract; HXSF = Hexane soluble fraction; CTCSF = Carbon tetrachloride soluble fraction; CSF = Chloroform soluble fraction; AQSF = Aqueous soluble fraction; $\mathrm{BHT}=$ Butylated hydroxytoluene; $\mathrm{GAE}=$ Gallic acid equivalent 
Table 2 Thrombolytic and membrane stabilizing activities of $L$. speciosa flower extract and soluble fractions

\begin{tabular}{lll}
\hline Samples/ Standard & \% of lysis of RBCs & $\begin{array}{l}\text { \% Inhibition of } \\
\text { haemolysis induced } \\
\text { by heat }\end{array}$ \\
\hline ME & $38.43 \pm 0.24$ & $32.62 \pm 0.18$ \\
HXSF & $47.20 \pm 0.49$ & $28.56 \pm 0.12$ \\
CTCSF & $64.80 \pm 0.27$ & $41.90 \pm 0.10$ \\
CSF & $46.91 \pm 0.62$ & $40.81 \pm 0.25$ \\
AQSF & $58.63 \pm 0.39$ & $16.03 \pm 0.37$ \\
Water & $3.79 \pm 0.55$ & - \\
Streptokinase & $66.77 \pm 0.36$ & - \\
Acetyl salicylic acid & - & $42.12 \pm 0.38$
\end{tabular}

$\mathrm{ME}=$ Methanolic crude extract; $\mathrm{HXSF}=$ Hexane soluble fraction; $\mathrm{CTCSF}=$ Carbon tetrachloride soluble fraction; $\mathrm{CSF}=$ Chloroform soluble fraction; $\mathrm{AQSF}=$ Aqueous soluble fraction

manifested by writhing in mice [50]. The samples were evaluated by determining their ability to inhibit writhing.

Each group consisted of five mice. Distilled water $(10 \mathrm{ml} / \mathrm{kg}$ ) and diclofenac sodium $(50 \mathrm{mg} / \mathrm{kg}$ body weight) were given orally to the mice of negative and positive control groups, respectively. The crude methanol extract (200 and $400 \mathrm{mg} / \mathrm{kg}$ doses) was administered orally to mice of other two groups. After $40 \mathrm{~min}, 1 \%$ volume/volume acetic acid (10 ml/kg dose) was injected intraperitonially. After giving a resting period of $10 \mathrm{~min}$, the number of writhing given by each animal was counted for the next $10 \mathrm{~min}$. The percent inhibition of pain induced by acetic acid was calculated according to the following formula:

Percentage inhibition

$=\frac{[\text { Mean number of writhing (control) }- \text { Mean number of writhing (test) }] \times 100 \%}{}$ Mean number of writhing (control)

\section{Central analgesic activity}

Tail flicking method was used to determine central analgesic activity [51]. Before administering anything, the tip of the tail (last 1-2 cm) of all mice was immersed on the radiant heat source. The tail flicking response was considered as the end point. For preventing damage to the tail, a cut off period of $15 \mathrm{~s}$ was set. Here, a total of twenty mice divided into four groups were used. Mice of negative control group were given $1 \%$ Tween- 80 in saline mixture $(0.1 \mathrm{ml} / 10 \mathrm{mg})$ orally while mice of positive control group received morphine $(2 \mathrm{mg} / \mathrm{kg}$ ) subcutaneously. The crude methanol extract (200 and $400 \mathrm{mg} / \mathrm{kg}$ doses) was administered orally to mice of other two groups. The tail flicking response was then recorded after $30 \mathrm{~min}, 60 \mathrm{~min}$ and $90 \mathrm{~min}$ of administration of

Table 3 Antimicrobial activity of test samples of L. speciosa

\begin{tabular}{|c|c|c|c|c|c|c|}
\hline \multirow[t]{2}{*}{ Test microorganisms } & \multicolumn{6}{|c|}{ Diameter of zone of inhibition (mm) } \\
\hline & ME & HXSF & CTCSF & CSF & AQSF & $\begin{array}{l}\text { Ciprofloxacin/ } \\
\text { Fluconazole } \\
\text { (30 } \mathrm{gg} / \text { disc) }\end{array}$ \\
\hline \multicolumn{7}{|l|}{ Gram positive bacteria } \\
\hline Bacillus cereus & $8.0 \pm 0.12$ & - & - & $7.00 \pm 0.92$ & - & $45 \pm 2.01$ \\
\hline Bacillus megaterium & $16.0 \pm 0.43$ & $15.0 \pm 0.73$ & - & - & - & $42 \pm 1.17$ \\
\hline Bacillus subtilis & $9.0 \pm 0.56$ & - & $9.0 \pm 0.33$ & - & - & $42 \pm 0.73$ \\
\hline Staphylococcus aureus & $10.0 \pm 0.57$ & - & $19.0 \pm 0.48$ & $7.0 \pm 1.45$ & $7.0 \pm 1.3$ & $42 \pm 0.23$ \\
\hline Micrococcus luteus & $9.0 \pm 0.16$ & - & $6.0 \pm 0.45$ & $7.0 \pm 1.11$ & $7.0 \pm 0.92$ & $42 \pm 0.56$ \\
\hline \multicolumn{7}{|l|}{ Gram negative bacteria } \\
\hline Escherichia coli & $8.0 \pm 0.54$ & - & $7.0 \pm 0.81$ & $7.0 \pm 0.45$ & - & $42 \pm 0.43$ \\
\hline Pseudomonas aeruginosa & $10.0 \pm 0.36$ & - & $7.0 \pm 0.32$ & $8.0 \pm 0.31$ & - & $42 \pm 1.11$ \\
\hline Salmonella paratyphi & $8.0 \pm 0.68$ & - & - & $10.0 \pm 0.55$ & $8.0 \pm 1.56$ & $47 \pm 2.33$ \\
\hline Salmonella typhi & - & - & $9.0 \pm 0.17$ & - & $9.0 \pm 0.41$ & $45 \pm 0.73$ \\
\hline Shigella boydii & $7.0 \pm 0.87$ & - & $6.0 \pm 0.66$ & $7.0 \pm 1.90$ & - & $34 \pm 0.58$ \\
\hline Shigella dysenteriae & $10.0 \pm 0.73$ & - & $9.0 \pm 0.25$ & $12.0 \pm 0.22$ & $7.0 \pm 0.83$ & $42 \pm 0.22$ \\
\hline Vibrio mimicus & $6.0 \pm 0.21$ & - & $6.0 \pm 0.16$ & $8.0 \pm 0.48$ & - & $40 \pm 0.45$ \\
\hline Vibrio parahemolyticus & $9.0 \pm 1.56$ & - & $6.0 \pm 1.12$ & $8.0 \pm 2.12$ & $7.0 \pm 0.21$ & $35 \pm 0.44$ \\
\hline \multicolumn{7}{|l|}{ Fungi } \\
\hline Saccharomyces cerevisiae & $7.0 \pm 1.12$ & - & $7.0 \pm 0.53$ & $7.0 \pm 1.43$ & $6.0 \pm 0.21$ & $38 \pm 0.11$ \\
\hline Aspergillus niger & $8.0 \pm 0.43$ & - & $8.0 \pm 0.48$ & $7.0 \pm 0.33$ & $5.0 \pm 0.54$ & $37 \pm 0.33$ \\
\hline
\end{tabular}

$\mathrm{ME}=$ Methanolic crude extract; HXSF = Hexane soluble fraction; CTCSF = Carbon tetrachloride soluble fraction; CSF = Chloroform soluble fraction; AQSF = Aqueous soluble fraction 
Table 4 Effect of L. speciosa flower extract on acetic acid-induced writhing in mice

\begin{tabular}{lll}
\hline Groups & Number of writhing & $\begin{array}{l}\text { Inhibition of } \\
\text { writhing (\%) }\end{array}$ \\
\hline $\begin{array}{l}\text { Control }(10 \mathrm{ml} / \mathrm{kg}) \\
\begin{array}{l}\text { Diclofenac sodium } \\
(50 \mathrm{mg} / \mathrm{kg})\end{array}\end{array}$ & 19.6 & 74.49 \\
$\begin{array}{l}\text { Methanol extract } \\
(200 \mathrm{mg} / \mathrm{kg})\end{array}$ & $19.41 \pm 0.26 \pm 0.68$ & 0.97 \\
$\begin{array}{l}\text { Methanol extract } \\
(400 \mathrm{mg} / \mathrm{kg})\end{array}$ & $16.33 \pm 0.12$ & 16.68 \\
\hline
\end{tabular}

Values are expressed as Mean \pm SD from the experiments

${ }^{*} P<0.05 ;{ }^{*} P<0.01$ vs. control; $n=5$

samples. The pain inhibition percentage (PIP) was calculated according to the following formula:

Pain inhibition percentage $(\mathrm{PIP})=\left(\left(\mathrm{T}_{1}-\mathrm{T}_{0}\right) / \mathrm{T}_{0}\right) \times 100$

where, $T_{1}$ is post-drug latency and $T_{0}$ is pre-drug latency.

\section{Hypoglycemic activity assay}

Tail tipping method was used to determine hypoglycemic effect of the test samples in mice [52]. At first, blood was withdrawn from the tip of the tail and the sugar level was measured by using glucometer. Here, a total of twenty mice divided into four groups were used. The mice of negative and positive control groups received $1 \%$ Tween-80 in saline mixture $(0.1 \mathrm{ml} / 10 \mathrm{mg})$ and Glibenclamide $(5 \mathrm{mg} / \mathrm{kg})$, respectively. The methanolic crude extract $(200 \mathrm{mg} / \mathrm{kg}$ and $400 \mathrm{mg} / \mathrm{kg}$ doses) was given orally to mice of treatment groups. After an hour, $10 \%$ glucose solution ( $2 \mathrm{~g} / \mathrm{kg}$ body weight) was given orally to all the mice. The blood sugar level was again recorded after $1^{\text {st }}$, $2^{\text {nd }}$ and $3^{\text {rd }}$ hour of administration of glucose solution.

\section{Phenobarbitone sodium-induced sleeping time}

In phenobarbitone sodium-induced sleeping time test [53], fifteen mice were equally divided into three groups. The treatment groups received the crude methanol extract (200 and $400 \mathrm{mg} / \mathrm{kg}$ body weight doses) while the control group received saline water containing Tween-80 solution alone. After $30 \mathrm{~min}$, all the animals received phenobarbitone sodium at a dose of $25 \mathrm{mg} / \mathrm{kg}$ body weight intraperitonially. Phenobarbitone sodium was given to induce sleep. All the mice were then monitored to observe the time of onset of sleep and total sleeping time.

\section{Statistical analysis:}

Three replicates of each sample were used for statistical analysis and all of the values are expressed as the mean \pm standard deviation (SD). The results were evaluated by a two-tailed non-parametric pair t-test. $P<0.05$ was considered statistically significant.

\section{Results}

Our research attempted to assess the crude methanol extract of $L$. speciosa flowers for different bioactivities by mice and non-mice based assays.

In antioxidant activity assay, the highest free radical scavenging activity was demonstrated by the chloroform soluble fraction of $L$. speciosa extract $\left(\mathrm{IC}_{50}=4.20 \pm 0.41 \mu \mathrm{g} / \mathrm{ml}\right)$. On the other hand, while evaluating the test samples for cytotoxic potencies, the hexane soluble fraction exhibited the lowest $\mathrm{LC}_{50}$ value $\left(\mathrm{LC}_{50}=2.00 \pm 0.31 \mu \mathrm{g} / \mathrm{ml}\right)$ compared to other samples (Table 1).

Among the test samples of $L$. speciosa, the carbon tetrachloride soluble fraction showed the highest capacity to promote lysis of clot $(64.80 \pm 0.27 \%$ of clot lysis $)$ as well as to inhibit haemolysis of RBCs under heat-induced condition $(41.90 \pm 0.10 \%)$. Both the findings were comparable to the standards used in the respective assays (Table 2).

In disc diffusion assay, all the test samples were evaluated by zones of inhibition which were formed by inhibiting the growth of different microorganisms. A $19.0 \mathrm{~mm}$ zone of inhibition was observed against Staphylococcus aureus. It was demonstrated by the carbon tetrachloride soluble fraction. Another $16.0 \mathrm{~mm}$ zone of inhibition was measured against Bacillus megaterium demonstrated by the crude methanol extract (Table 3).

L. speciosa flower extract was found to exhibit dose dependent inhibition of acetic acid induced writhing in Swiss albino mice. The outcome of peripheral analgesic activity assay was not found to be significant compared to the standard diclofenac sodium (Table 4).

In central analgesic activity assay by tail-flick method, $48.24 \%$ elongation of the reaction time was observed after $30 \mathrm{~min}$ of administration of the crude methanol extract (400 mg/kg body weight) of the flowers of $L$. speciosa. (Tables 5 and 6).

Table 5 Effect of $L$. speciosa flower extract on tail flicking time of mice

\begin{tabular}{lllll}
\hline Groups & Latency period & & & \\
\cline { 2 - 5 } & 0 min & $30 \min$ & $60 \min$ & $90 \mathrm{~min}$ \\
\hline Control & $6.03 \pm 0.47$ & $6.26 \pm 0.57$ & $6.16 \pm 0.89$ & $15.96 \pm 1.17$ \\
Morphine $(2 \mathrm{mg} / \mathrm{kg})$ & $10.80 \pm 0.91$ & $16.5 \pm 1.03$ & $7.40 \pm 0.86$ & $16.16 \pm 1.07$ \\
Methanol extract $(200 \mathrm{mg} / \mathrm{kg})$ & $6.80 \pm 0.54$ & $4.25 \pm 0.22$ & $5.41 \pm 0.75$ \\
Methanol extract $(400 \mathrm{mg} / \mathrm{kg})$ & $6.44 \pm 0.33$ & $3.24 \pm 0.43$ & $5.70 \pm 0.61$ & $4.22 \pm 0.79$ \\
\hline
\end{tabular}


Table 6 Anti-nociceptive activity of methanolic crude extract of L. speciosa flower

\begin{tabular}{llll}
\hline Groups & \multicolumn{3}{l}{ \% Pain inhibition } \\
\cline { 2 - 4 } & $30 \mathrm{~min}$ & $60 \mathrm{~min}$ & $90 \mathrm{~min}$ \\
\hline Morphine $(2 \mathrm{mg} / \mathrm{kg})$ & $163.58 \pm 2.38$ & $159.09 \pm 2.03$ & $159.39 \pm 1.89$ \\
$\begin{array}{l}\text { Methanol extract } \\
(200 \mathrm{mg} / \mathrm{kg})\end{array}$ & $32.11 \pm 0.44$ & $20.13 \pm 1.03$ & $13.16 \pm 0.72$ \\
$\begin{array}{l}\text { Methanol extract } \\
(400 \mathrm{mg} / \mathrm{kg})\end{array}$ & $48.24 \pm 0.91$ & $7.47 \pm 0.27$ & $32.26 \pm 0.41$
\end{tabular}

Values are expressed as Mean \pm SD from the experiments

L. speciosa flower extract was found to lower the blood sugar level significantly while evaluating its hypoglycemic activity by tail tipping method. Its efficacy was evident even after 3rd hour of administration of the glucose solution. The blood sugar level was reduced by 48.85 and $56.12 \%$ at 200 and $400 \mathrm{mg} / \mathrm{kg}$ body weight doses, respectively (Table 7 and Table 8).

In phenobarbitone sodium-induced sleeping time test, L. speciosa flower extract delayed the onset of sleep (30.22 $\mathrm{min}$ and $38.61 \mathrm{~min}$ at 200 and $400 \mathrm{mg} / \mathrm{kg}$ body weight doses, respectively) compared to the control group $(15.8 \mathrm{~min})$. The extract was also found to shorten total sleeping time (99.45 min and $107.6 \mathrm{~min}$ at 200 and $400 \mathrm{mg} / \mathrm{kg}$ body weight doses, respectively) compared to the control group (118.6 min) (Table 9).

\section{Discussion}

The free radical scavenging and cytotoxic activities of $L$. speciosa test samples could be attributed to the high phenolic and flavonoid content in the leaves and flower petals and also to some phytocomponents like corosolic acid, ellagic acid, gallic acid and quercetin that have been found to be present in L. speciosa. These compounds are well known for their antioxidant potencies [54-58]. Again quercetin has been reported to have cytotoxic potential from its ability to increase the ROS production [59]. Treatment of human prostate cancer was reported to be successful with gallic acid [60].

The observations in thrombolytic activity assay may have revolutionary significance since it may lead to the discovery of new cardiovascular drugs [1]. Blood clot formation is a complex process that involves series of events [61]. The ability of the test samples to promote thrombolysis may pave the way of discovering novel thrombolytic agents from L. speciosa flower extract. In addition, according to ayurvedic medicine, arjunolic acid can prevent necrosis of the myocardium and clot formation [62]. This phytoconstituent has already been extracted from $L$. specios $a$ and its presence can be correlated with the extract's thrombolytic potential.

L. speciosa extract and its aqueous and organic soluble fractions reduced heat-induced haemolysis of RBC. Membranes of lysosome and red blood cells have similar structural features [63]. Inflammation occurs due to leakage of serum protein and fluids into tissues. By decreasing membrane permeability and subsequently preventing drainage of proteins and fluids, membrane stability can be ensured and anti-inflammatory response can be manifested [64]. Arjunolic acid has been proved to have the ability to affect cyclooxygenase catalyzed arachidonic acid metabolism. This phytochemical might have contributed to the plant's anti-inflammatory activity $[62,65]$. On the other hand, quercetin and isoquercitrin were found to be effective eosinophilic inflammation suppressors. These phytocomponents can be used for treating allergies [66]. Again, gallic acid was reported to exhibited anti-inflammatory activity in animal model [67]. All these phytochemicals reported from L. speciosa, might have contributed to its membrane stabilizing potential.

Test samples from L. speciosa flowers were observed to give zones of inhibition against different microorganisms due to the presence of well known plant metabolites [68]. The leaf and seed extracts of L. speciosa showed prominent antimicrobial activity against different micro-organisms [69, 70]. Arjunolic acid and Asiatic acid, reported to be isolated from L. speciosa, have been proved to possess antimicrobial potencies [62, 71].

The hypoglycemic activity of $L$. speciosa extract may be due to the presence of corosolic acid in the plant. This phytocomponent not only increases insulin secretion [17, 72] but also stimulates cellular glucose uptake [73]. In short, corosolic acid has insulin-like effect [73-75]. Like corosolic acid, three active ellagitannins: lagerstroemin, flosin $\mathrm{B}$ and reginin $\mathrm{A}$, reported from L. speciosa extracts, also promote glucose uptake in fat cells [15, 76-79]. On the other hand, corosolic acid has been found to have both free radical scavenging and hypoglycemic properties in animal model. It

Table 7 Effect of L. speciosa flower extract on blood glucose of Swiss albino mice

\begin{tabular}{|c|c|c|c|c|}
\hline \multirow[t]{2}{*}{ Groups } & \multicolumn{4}{|c|}{ Blood Glucose Level (mmol/L) } \\
\hline & 0 min & $1^{\text {st }}$ hour & $2^{\text {nd }}$ hour & $3^{\text {rd }}$ hour \\
\hline Control Group & $5.98 \pm 0.12$ & $5.72 \pm 0.49$ & $5.70 \pm 0.34$ & $5.63 \pm 0.56$ \\
\hline Standard Group (5 mg/kg) & $5.96 \pm 0.31$ & $2.00 \pm 0.07$ & $2.54 \pm 0.13$ & $2.76 \pm 0.16$ \\
\hline Methanol extract $(200$ mg/kg) & $4.66 \pm 0.23$ & $5.22 \pm 0.37$ & $3.04 \pm 0.11^{*}$ & $2.88 \pm 0.33^{* *}$ \\
\hline Methanol extract $(400$ mg/kg) & $4.64 \pm 0.41$ & $2.88 \pm 0.83^{* *}$ & $2.60 \pm 0.47^{* *}$ & $2.47 \pm 0.66^{* *}$ \\
\hline
\end{tabular}

Values are expressed as mean $\pm \mathrm{SD} ;{ }^{*} P<0.05 ;{ }^{* *} P<0.01$ vs. control; $n=5$ 
Table 8 Percentage of blood glucose level reduction in Swiss albino mice

\begin{tabular}{llll}
\hline Groups & \multicolumn{3}{l}{ \% of blood glucose level reduction } \\
\cline { 2 - 4 } & $1^{\text {st }}$ hour & $2^{\text {nd }}$ hour & $3^{\text {rd }}$ hour \\
\hline Control Group & 4.35 & 4.68 & 5.85 \\
Standard Group (5 mg/kg) & 65.03 & 55.43 & 50.98 \\
Methanol extract $(200 \mathrm{mg} / \mathrm{kg})$ & 8.74 & 46.67 & 48.85 \\
Methanol extract $(400 \mathrm{mg} / \mathrm{kg})$ & 49.65 & 54.39 & 56.12 \\
\hline
\end{tabular}

has been suggested that ROS destroys $\beta$-cells of pancreas [25]. Thus by scavenging free radicals, corosolic acid is indirectly keeping $\beta$-cells of pancreas functional thereby demonstrating hypoglycemic effect $[9,22,80]$. However, recently a glucose uptake assay has indicated that not corosolic acid but gallotannins can be accounted for the hypoglycemic activity. Gallotannins are phytocomponents already reported from the species under investigation. Among the gallotannins, penta-O-galloyl-glucopyranose stimulates transportation of glucose into the cell to a greater extent than lagerstroemin [81]. Another phytocomponent reported from the plant is arjunolic acid which was found to be beneficial against both type I and type II diabetes [62].

Arjunolic acid might be credited for the analgesic activity of $L$. speciosa extract since this phytocomponent has been reported to have influences on COX pathway [62].

The outcome of the assay in which sleep was induced using phenobarbitone sodium, is a major finding and need further investigation for phytochemicals responsible for the effect.

\section{Conclusion}

Although $L$. speciosa is an ornamental plant and planted as a road side tree in Bangladesh, the plant has long history of folkloric uses. Investigation on different plant parts has led to the isolation of active phytochemicals and understanding of medicinal benefits of the plant that can be correlated to its traditional uses. From our study, we can come to the conclusion that like other plant parts, the flowers of the plant have major bioactivities. L. speciosa samples demonstrated noteworthy potentials in scavenging free radicals, promoting clot lysis and stabilizing RBC membrane under heat induced condition. Analgesic activity was not found to be that prominent but the outcome

Table 9 Effect of L. speciosa flower extract on phenobarbitone sodium-induced sleep

\begin{tabular}{lll}
\hline Groups & $\begin{array}{l}\text { Time of onset } \\
\text { of sleep (minutes) }\end{array}$ & $\begin{array}{l}\text { Total sleeping } \\
\text { time (minutes) }\end{array}$ \\
\hline Control $(10 \mathrm{ml} / \mathrm{kg})$ & $15.8 \pm 1.19$ & $118.6 \pm 2.81$ \\
Methanol extract $(200 \mathrm{mg} / \mathrm{kg})$ & $30.22 \pm 2.20$ & $99.45 \pm 2.85$ \\
Methanol extract $(400 \mathrm{mg} / \mathrm{kg})$ & $38.61 \pm 1.76$ & $107.6 \pm 3.21$ \\
\hline
\end{tabular}

Values are expressed as Mean \pm SD from the experiments of hypoglycemic activity assay justifies its traditional use in diabetes. Recent objective of the global pharmaceutical industries is to develop novel drugs of plant origin on the basis of the history of traditional uses of those plants. The phytoconstituents that are actually responsible for the observed bioactivities, should be isolated by different experimental methods, identified and finally can be involved in biological activity assays. Thus, it will be possible to understand their mechanism of action. Therefore, in the conclusion, it can be said that L. speciosa flowers are excellent candidate for future investigation for potent phytocomponents with biological activities.

\section{Abbreviations}

BHT: Butylated hydroxytoluene; CNS: Central nervous system; COX: Cyclooxygenase; DMSO: dimethylsulfoxide; DPPH: 1, 1-diphenyl-2-picrylhydrazyl; GAE: Gallic acid equivalent; ICDDR, B: International Centre for Diarrheal Diseases and Research, Bangladesh; RBCs: Red blood cells; ROS: Reactive Oxygen Species

\section{Funding}

No funding was received for this study.

Availability of data and materials

All data generated or analyzed during this study are included in this published article.

Authors' contributions

The study was conceived and designed by TS and MSR. HM collected the plant, did the extraction, and conducted the experiments. TS performed statistical analysis, interpreted data and drafted the manuscript which was evaluated by all authors. All authors have read and approved the final manuscript.

\section{Ethics approval and consent to participate}

The Swiss Academy of Medical Sciences and the Swiss Academy of Sciences formulated Ethical Principles and Guidelines for Scientific Experiments on Animals (1995) were followed for in vivo study. All the experiments were performed under the approval of Ethics Committee of State University of Bangladesh through the submission of a research protocol (FHU/SUB/23/ 2014) before the study.

Consent for publication

Not relevant.

\section{Competing interests}

The authors declare that they have no competing interests.

\section{Publisher's Note}

Springer Nature remains neutral with regard to jurisdictional claims in published maps and institutional affiliations.

\section{Author details}

'Department of Pharmaceutical Chemistry, Faculty of Pharmacy, University of Dhaka, Dhaka, Bangladesh. ${ }^{2}$ Department of Chemistry, Faculty of Science, University of Dhaka, Dhaka, Bangladesh. ${ }^{3}$ Department of Pharmacy, State University of Bangladesh, Dhaka, Bangladesh.

Received: 26 February 2017 Accepted: 11 July 2018

Published online: 06 August 2018

References

1. Hussain F, Islam MA, Bulbul L, Moghal MMR, Hossain MS. In vitro thrombolytic potential of root extracts of four medicinal plants available in Bangladesh. Anc Sci Life. 2014;33(3):162-4. 
2. Takano J. Lagerstroemia speciosa L. (Banaba or Queen's Flower) - Wonders of Botanical Herbs: Pyroenergen. 2013. https://www.pyroenergen.com/ other-products/banaba-plant.htm (Accessed 2 Jan 2017).

3. Ragasa CY, Ngo HT, Rideout JA. Terpenoids and sterols from Lagerstroemia speciosa. J Asian Nat Prod Res. 2005;7(1):7-12.

4. Wei D. Philippine medicinal plants - Banaba: Stuart Xchange. 2013. http:// www.stuartxchange.org/Banaba.html. (Accessed 2 Jan 2017)

5. Park C, Lee JS. Banaba: the natural remedy as antidiabetic drug. Biomed Res 2011;22(2):125-9.

6. Priya TT, Sabu MC, Jolly CL. Amelioration of cisplatin induced nephrotoxicity in mice by ethyl acetate extracts of Lagerstroemia speciosa L. J Basic Clin Physiol Pharmacol. 2007;18(4):289-98.

7. Priya $\Pi$, Sabu MC, Jolly CL. Hepatoprotective and free radical scavenging activities of Lagerstroemia speciosa Linn. Oriental Pharma Exp Med. 2009:9(3):225-31.

8. Kalidas S, Kameswari B, Devi P, Madhumitha B, Meera R, Merlin NJ. Phytophysico chemical evaluation, antioxidant activities and diuretic activity of leaves of Lagerstroemia reginae. Asian J Res Chem. 2008;1 (2):83-7.

9. Saumya SM, Piler MB. Antioxidant effect of Lagerstroemia speciosa Pers (Banaba) leaf extract in streptozotocin-induced diabetic mice. Indian J Exp Biol. 2010:49(2):125-31.

10. Anil P, Manish S, GarvendraS R, Chand T. In Vitro antioxidant studies of Lagerstroemia speciosa leaves. Pharmacog J. 2010;2(10):357-60.

11. Lai KH, Darah I, Wong CT, Afifah S, Lim SH. In vitro antibacterial activity and cytotoxicity of Lagerstroemia speciosa bark extract. Indian J Pharm Sci. 2016; 78(2):273-7.

12. Nasrin F, Ahmad S, Kamrunnahar. Evaluation of antimicrobial, antioxidant and cytotoxic activities of methanolic extracts of Lagerstroemia speciosa leaves and barks. J Appl Pharm Sci. 2014;2(10):142-7.

13. Deocaris CC, Aguinaldo RR, Ysla JLY, Asencion AS, Mojica EE. Hypoglycemic activity of irradiated Banaba (Lagerstroemia speciosa Linn.) leaves. J Appl Sci Res. 2005:1 (1):95-8

14. Hussain F, Ganguly A, Hossain MS, Rahman SMA. Analgesic and antidiarrhoeal activities of Lagerstroemia speciosa roots in experimental animal model. Dhaka Univ J Pharm Sci. 2014;13(1):57-62.

15. Stohs SJ, Miller H, Kaats GR. A review of the efficacy and safety of banaba (Lagerstroemia speciosa) and corosolic acid. Phytother Res. 2012;26(3):317-24.

16. Garcia F. On the hypoglycemic effect of decoction of Lagerstroemia speciosa (banaba) administered orally. J Philippine Med Assoc. 1940;20: 395-402.

17. Kakuda T, Sakane I, Takihara T, Ozaki Y, Takeuchi H, Kuroyanagi M. Hypoglycemic effect of extracts from Lagerstroemia speciosa L. leaves in genetically diabetic KK-AY mice. Biosci Biotechnol Biochem. 1996; 60(2):204-8.

18. Tanquilut NC, Tanquilut MRC, Estacio MAC, Torres EB, Rosario JC, Reyes BAS. Hypoglycemic effect of Lagerstroemia speciosa (L.) Pers. on alloxan-induced diabetic mice. J Med Plants Res. 2009:3(12):1066-71.

19. Mishra YC. Hypoglycemic activity of leaves of Lagerstroemia speciosa (L) Pers. Indian J Pharmacol. 1990;22:174-6.

20. Shareef SM, Sridhar I, Mishra SS, Venkata RY. Evaluation of hypoglycemic effect of Lagerstroemia speciosa (banaba) leaf extract in alloxan induced diabetic rabbits. Int J Med Res Health Sci. 2012;2(2):217-22.

21. Saha BK, Sarker AK, Ahmed K, Krishna B, Hossain ME. Effects of Lagerstroemia speciosa L. extracts on alloxan induced diabetic rats. Hamdard Medicus. 2006;XLIX:23-8.

22. Saha BK, Bhuiyan MNH, Mazumder K, Haque KMF. Hypoglycemic activity of Lagerstroemia speciosa L. extract on streptozotocin-induced diabetic rat: underlying mechanism of action. Bangladesh J Pharmacol. 2009;4(2):79-83.

23. Singh LS, Singh NS. Devi1 MA. Hypoglycaemic effect of Lagerstroemia speciosa in type 2 diabetic rats. J Med Plant Res. 2014;8(25):899-902.

24. Garcia F. Plantisul tablets in the treatment of diabetes mellitus. J Philippine Med Assoc. 1956;31(5):216-4

25. Ikeda Y, Chen JT, Matsuda T. Effectiveness and safety of banabamin tablet containing extract from banaba in patients with mild type-2 diabetes. Japanese Pharmacol Ther. 1999;27:829-35.

26. Oberley LW. Free radicals and diabetes. Free Radic Biol Med. 1988; 5(2):113-24

27. Judy WW, Hari SP, Stogsdill WW, Judy JS, Naguib YM, Passwater R. Antidiabetic activity of a standardized extract (Glucosol) from Lagerstroemia speciosa leaves in type II diabetics. A dose-dependence study. J Ethnopharmacol. 2003; $87(1): 115-7$
28. Pal M, Thareja D, Majee C. Lagerstroemia species: a review. Int J Pharm. 2016 6(1):95-8

29. Bellah SF, Islam KMR, Karim MR, Hossain MJ, Ashrafudoulla M, Hasan M. Phytochemical and Pharmacological Screening of the fruits of Lagerstroemia speciosa (L.) pers. World J Pharm Sci. 2016;4(5):205-11.

30. Gupta A, Agrawal VK, Rao CV. Exploration of analgesic and antiinflammatory potential of Lagerstroemia speciosa. J Appl Pharm Sci. 2017;7(2):156-61.

31. Chan EWC, Tan LN, Wong SK. Phytochemistry and pharmacology of Lagerstroemia speciosa: a natural remedy for diabetes. Int I Herbal Med. 2014;2(2):100-5

32. Xu YM, Sakai T, Tanaka T, Nonaka G, Nishioka I. Tannins and related compounds CVI Preparation of aminoalditol derivatives of hydrolysable tannins having $\alpha-$ and $\beta$-glucopyranose cores, and its application to the structure elucidation of new tannins reginins $A$ and $B$ and flosin $A$ isolated from Lagerstroemia flos-reginae Retz. Chem Pharm Bull. 1991; 39(3):639-46.

33. Xu YM, Tanaka T, Nonaka G, Nishioka I. Tannins and related compounds CVII Structure elucidation of three new monomeric and dimeric ellagitannins flosin B reginins $C$ and D isolated from Lagerstroemia flosreginae Retz. Chem Pharm Bull. 1991;39(3):647-50

34. Tanaka T, Tong HH, Xu YM, Ishimaru K, Nonaka G, Nishioka I. Tannins and related compounds. CXVIII Isolation and characterization of three new ellagitannins lagerstannins $A, B$ and $C$ having a gluconic acid core from Lagerstroemia speciosa (L.) Pers. Chem Pharma Bull. 1992;40(11):2975-80.

35. Bai N, He K, Roller M, Zheng B, Chen X, Shao Z, Peng T, Zheng Q. Active compounds from Lagerstroemia speciosa insulin like glucose uptake stimulatory/inhibitory and adipocyte differentiation-inhibitory activities in 3T3-L1 cells. J Agric Food Chem. 2008;56(24):11668-74.

36. Okada Y, Omae A, Okuyama T. A new triterpenoids isolated from Lagerstroemia speciosa (L.) Pers. Chem Pharm Bull. 2003;51(4):452-4.

37. Hou W, Li Y, Zhang Q, Wei X, Peng A, Chen L, Wei Y. Triterpene acids isolated from Lagerstroemia speciosa leaves as a-glucosidase inhibitors. Phytother Res. 2009;23(5):614-8.

38. Unno T, Sugimoto A, Kakuda T. Xanthine oxidase inhibitors from the leaves of Lagerstroemia speciosa (L.) Pers. J Ethnopharmacol. 2004; 93(2-3):391-5.

39. Sarker R, Sharmin T, Islam F, Chowdhury SR. In vitro antioxidant, total phenolic, membrane stabilizing and antimicrobial activity of Allamanda cathartica L.: a medicinal plant of Bangladesh. J Med Plants Res. 2014;8(1):63-7.

40. Sharmin T, Islam F, Kaisar MA, Mansur MAM, Sikder MA, Rashid MA. Chemical and Biological Investigations of Albizia chinensis (Osbeck.) Merr. J Phys Sci. 2014;25(2):29-38.

41. Sharmin T, Sarker PK, Islam F, Chowdhury SR, Quadery TM, Mian MY, Rahman SMA, Chowdhury ZS, Ullah MS. Investigation of biological activities of Allamanda blanchetii, the violet Allamanda. J Pharm Res. 2013:6(7):761-4.

42. Vanwagenen $B C$, Larsen $\mathrm{R}$, Cardellina JH, Randazzo D, Lidert ZC, Swithenbank C. Ulosantoin, a potent insecticide from the sponge Ulosa ruetzleri. J Org Chem. 1993;58(2):335-7.

43. Hawk PB, Oser L, Summerson WH. Practical physiological chemistry. $13^{\text {th }}$ ed. USA: McGraw Hill Book Company; 1954

44. Harbertson J, Spayd S. Measuring phenolics in the winery. Am J Enol Vitic 2006;57:280-8

45. Brand-Williams W, Cuvelier ME, Berset C. Use of free radical method to evaluate antioxidant activity. Lebensm Wiss Technol. 1995;28(1):25-30.

46. Meyer BN, Ferringni NR, Puam JE, Lacobsen LB, Nichols DE, McLaughlin JL. Brine shrimp: a convenient general bioassay for active constituents. Planta Med. 1982:45(5):31-2.

47. Prasad S, Kashyap RS, Deopujari JY, Purohit HJ, Taori GM, Daginawala HF. Effect of Fagonia arabica (Dhamasa) on in vitro thrombolysis. BMC Complement Alternat Med. 2007;7:36.

48. Omale J, Okafor PN. Comparative antioxidant capacity, membrane stabilization, polyphenols composition and cytotoxicity of the leaf and stem of Cissus multistriata. Afr J Biotechnol. 2008;7(17):3129-33.

49. Bayer AW, Kirby WMM, Sherris JC, Turck M. Antibiotic susceptibility testing by a standardized single disc method. Am J Clin Pathol. 1966;45(4):493-6.

50. Kaushik D, Kumar A, Kaushik P, Rana AC. Analgesic and anti-inflammatory activity of Pinus roxburghii Sarg. Adv Pharmaco Sci. 2012; https://doi.org/10. 1155/2012/245431.

51. Pizziketti RJ, Pressman NS, Geller E, Adler MW. Rat cold water tail-flick: a novel analgesic test that distinguishes opioid agonist from mixed agonistantagonist. Eur J Pharmacol. 1985;119(1-2):23-9. 
52. Durschlag M, Wurbel H, Stauffacher M, Von Holst D. Repeated blood collection in the laboratory mouse by tail incision-modification of an old technique. Physiol Behav. 1996;60(6):1565-8.

53. Williamson EM, Okpako DT, Evans FJ. Pharmacological methods in phytotherapy research: selection, preparation and pharmacological evaluation of plant material, vol 1. $1^{\text {st }}$ ed. England: John Willey \& Sons; 1996.

54. Priya $\mathrm{TT}$, Sabu $\mathrm{MC}$, Jolly $\mathrm{Cl}$. Free radical scavenging and anti-inflammatory properties of Lagerstroemia speciosa (L). Inflammopharmacology. 2008; 16(2008):182-7.

55. Tiwary BK, Dutta S, Dey P, Hossain M, Kumar A, Bihani S, Nanda AK, Chaudhuri TK, Chakraborty R. Radical scavenging activities of Lagerstroemia speciosa (L.) Pers. petal extracts and its hepato-protection in $\mathrm{CCl}_{4}$-intoxicated mice. BMC Complement Alternat Med. 2017:17:55.

56. Yamaguchi Y, Yamada K, Yashikawa N, Nakamura K, Haginaka J, Kunimoto M. Corosolic acid prevents oxidative stress, inflammation and hypertension in SHR/NDmcr-cp rats, a model of metabolic syndrome. Life Sci. 2006;79(26): 2474-9.

57. Priyadarsini KI, Khopde SM , Kumar SS, Mohan H. Free radical studies of ellagic Acid, a natural phenolic antioxidant. J Agric Food Chem. 2002;50(7): 2200-6

58. Zhang M, Swarts SG, Yin L, Liu C, Tian Y, Cao Y, Swarts M, Yang S, Zhang SB, Zhang K, Ju S, Olek DJ Jr, Schwartz L, Keng PC, Howell R, Zhang L, Okunieff P. Antioxidant properties of quercetin. Adv Exp Med Biol. 2011;701:283-9.

59. Matsuo M, Sasaki N, Saga K, Kaneko T. Cytotoxicity of flavonoids toward cultured normal human cells. Biol Pharm Bull. 2005;28(2):253-9.

60. Russell LH Jr, Mazzio E, Badisa RB, Zhu ZP, Agharahimi M, Millington DJ, Goodman CB. Differential cytotoxicity of triphala and its phenolic constituent gallic acid on human prostate cancer LNCap and normal cells. Anticancer Res. 2011;31(11):3739-45.

61. Furie B, Furie BC. Mechanisms of thrombus formation. N Engl J Med. 2008; 359:938-49

62. Hemalatha T, Pulavendran S, Balachandran C, Manohar BM, Puvanakrishnan R. Arjunolic acid: a novel phytomedicine with multifunctional therapeutic applications. Indian J Exp Biol. 2010;48(3):238-47.

63. Mounnissamy VM, Kavimani S, Balu V, Drlin QS. Evaluation of antiinflammatory and membrane stabilizing properties of ethanol extract of Canjera rehedi. Iranian J Pharmacol Ther. 2008;6:235-7.

64. Chaitanya R, Sandhya S, David B, Vinod KR, Murali S. HRBC Membrane stabilizing property of root, stem and leaf of Glochidion velutinum. Int J Res Pharm Biomed Sci. 2011;2(1):256-9.

65. Oweyele B, Oloriegbe YY, Balaogun EA, Soladoye AO. Analgesis and anti-inflammatory properties of Nelsonia canescens leaf extract. J Ethnopharmacol. 2005;99(1):153-6.

66. Rogerio AP, Kanashiro A, Fontanari C, da Silva EV, Lucisano-Valim YM, Soares EG, Faccioli LH. Anti-inflammatory activity of quercetin and isoquercitrin in experimental murine allergic asthma. Inflamm Res. 2007; 56(10):402-8.

67. Kroes BH, van den Berg AJ, Quarles van Ufford HC, van Dijk H, Labadie RP. Anti-inflammatory activity of gallic acid. Planta Med. 1992;58(6):499-504.

68. Laruan LMV, Balangcod T, Balangcod K, Patasil M, Aostol O, Manuel J, Cortez S, Vallejo V. Phytochemical and antibacterial study of Lagerstroemia speciosa (L.) Pers. and its ethnomedicinal importance to indigenous communities of Benguet Province, Philippines. Indian J Tradit Knowl. 2013;12(3):379-83.

69. Ambujakshi HR, Surendra V, Haribabu T, Divakar G. Antibacterial activity of leaves of Lagerstroemia speciosa (L) Pers. J Pharm Res. 2009;2(6):1028.

70. Sinhababu A, Basak B, Laskar S, Chakrabarty D, Sen SK. Effect of different fractions of petroleum ether ( $60-80$ degrees) extract of the seeds of Lagerstroemia speciosa (Linn. Ex Murray) Pers. on some microorganisms. Hindu Antibio Bull. 1994;36(1-2):39-45.

71. Liu WH, Liu TC, Mong MC. Antibacterial effects and action modes of asiatic acid. Biomedicine (Taipei). 2015;5(3):16.

72. Shi L, Zhang W, Zhou Y, Zhang Y, Li J, Hu L, Li J. Corosolic acid stimulates glucose uptake via enhancing insulin receptor phosphorylation. Eur J Pharmacol. 2008:584(1):21-9.

73. Liu F, Kim J, Li Y, Liu X, Li J, Chen X. An extract of Lagerstroemia speciosa L. has insulin-like glucose uptake-stimulatory and adipocyte differentiationinhibitory activities in 3T3-L1 cells. J Nutr. 2001;131(9):2242-7.

74. Fukushima M, Matsuyama F, Ueda N, Egawa K, Takemoto J, Kajimoto Y, Yonaha N, Miura T, Kaneko T, Nishi Y, Mitsui R, Fujita Y, Yamada Y, Seino Y. Effect of corosolic acid on postchallenge plasma glucose levels. Diabetic Res Clin Pract. 2006;73(2):174-7
75. Miura T, Itoh Y, Kaneko T, Ueda N, Ishida T, Fukushima M, Matsuyama F, Seino Y. Corosolic acid induces GLUT4 translocation in genetically type 2 diabetic mice. Biol Pharm Bull. 2004;27(7):1103-5.

76. Hayashi T, Maruyama H, Kasai R, Hattori K, Takasuga S, Hazeki O, Yamasaki K, Tanaka T. Ellagitannins from Lagerstroemia speciosa as activators of glucose transport in fat cells. Planta Med. 2002;68(2):173-5.

77. Miura T, Ueda N, Yamada K, Fukushima M, Ishida T, Kaneko T, Matsuyama F, Seino Y. Antidiabetic effects of corosolic acid in KK-ay diabetic mice. Biol Pharm Bull. 2006;29(3):585-7.

78. Murakami C, Myoga K, Kasai R, Ohtani K, Kurokawa T, Ishibashi S, Dayrit F, Padolina WG, Yamasaki K. Screening of plant constituents for effect on glucose transport activity in Ehrlich ascites tumour cells. Chem Pharm Bull. 1993:41(12):2129-31.

79. Saha BK, Bhuiyan NH, Mazumder K, Haque KMF. Hypoglycemic activity of Lagerstroemia speciosa L. extract on streptozotocin-induced diabetic rat: underlying mechanism of action. Bangladesh J Pharmacol. 2009;4(2):79-83.

80. Kaneto H, Kajimoto Y, Miyagawa J, Matsuoka T, Fujitani Y, Umayahara Y, Hanafusa T, Matsuzawa Y, Yamasaki Y, Hori M. Beneficial effects of antioxidants in diabetes: possible protection of pancreatic $\beta$-cell against glucose toxicity. Diabetes. 1999;48(12):2398-406.

81. Klein G, Kim J, Himmeldirk K, Cao Y, Chen X. Antidiabetes and anti-obesity activity of Lagerstroemia speciosa. Evid Based Complement Alternat Med. 2007;4(4):401-7.
Ready to submit your research? Choose BMC and benefit from:

- fast, convenient online submission

- thorough peer review by experienced researchers in your field

- rapid publication on acceptance

- support for research data, including large and complex data types

- gold Open Access which fosters wider collaboration and increased citations

- maximum visibility for your research: over $100 \mathrm{M}$ website views per year

At BMC, research is always in progress.

Learn more biomedcentral.com/submissions 